TARNOWSKIE STUDIA TEOLOGICZNE 36 (2017) NR 2, S. 107-122 http://dx.doi.org/10.15633/tst.2618

Arkadiusz Mirosław Czaja OFM ${ }^{1}$

UNIWERSYTET IM. ADAMA MICKIEWICZA W POZNANIU

\title{
Prawne aspekty urzędu obrońcy węzła w procesie o stwierdzenie nieważności małżeństwa
}

Rozważając problematykę związaną z urzędem obrońcy węzła w procesie o stwierdzenie nieważności małżeństwa, należy już na wstępie zaznaczyć, że jest to urząd konieczny dla dobra wspólnego Kościoła katolickiego. Przesłanką do jego ustanowienia była ochrona dobra publicznego. Właśnie w odniesieniu do procesu o stwierdzenie nieważności małżeństwa zostaną wskazane w treści artykułu aspekty prawne dotyczące urzędu obrońcy węzła.

\section{Geneza urzędu obrońcy węzła małżeńskiego}

Głównym celem powołania do życia urzędu obrońcy węzła małżeńskiego było wyposażenie go w odpowiednie narzędzia ochrony prawnej, do których należała obrona ważności węzła w procesie o stwierdzenie nieważności małżeństwa. Miało to spowodować wyeliminowanie istniejących nadużyć w kościelnych procesach oraz naprawę postępującego ówcześnie osłabienia życia religijnego wśród chrześcijan². Papież Benedykt xıv Konstytucją apostolską Dei miseratione - ogłoszoną 3 listopada 1741 roku - ustanowił urząd obrońcy węzła. Powodem jego ustanowienia było położenie kresu

1 Arkadiusz Mirosław Czaja ofm - doktor nauk prawnych; wykładowca prawa kanonicznego na Wydziale Teologicznym Uniwersytetu im. Adama Mickiewicza w Poznaniu; przewodniczący Komisji Prawnej w Prowincji św. Franciszka z Asyżu w Polsce i Komisji Statutowej Rady Narodowej Franciszkańskiego Zakonu Świeckich w Polsce; sędzia Sądu Diecezji Toruńskiej oraz adwokat w procesach karnoadministracyjnych, a także przełożony domu zakonnego w Miłakowie.

2 Por. M. Greszata, Iudicium cum principiis. Kodeksowa weryfikacja wybranych zasad procesowych w kanonicznych sprawach o nieważność małżeństwa, Lublin 2008, s. 230; W. Wenz, P. Wróblewski, Urząd obrońcy węzła i procesowe decyzje sędziego na etapie wyrokowania, Warszawa 2007, s. 24. 
nadużyciom, jakie miały miejsce w procesach o stwierdzenie nieważności małżeństwa ${ }^{3}$. Wynikały one przede wszystkim $\mathrm{z}$ braku roztropności sędziów kościelnych przy orzekaniu nieważności małżeństwa ${ }^{4}$. Nadużycia te również miały miejsce w Xvin wieku w praktyce sądowej w Królestwie Polskim 5 . W 1743 roku papież w był zmuszony skierować list do biskupów polskich, w którym przypominał o obowiązującym prawie i zagroził, że jeśli nie przeprowadzą reformy trybunałów kościelnych w Polsce, to sprawy dotyczące ważności małżeństw będą rozpatrywane przez Stolicę Apostolską ${ }^{6}$.

Zgodnie z konstytucją apostolską Benedykta XIV wymogiem do stwierdzenia nieważności małżeństwa było orzeczenie dwóch zgodnych wyroków przez odrębne instancje sądowe, a obrońca węzła małżeńskiego był zobowiązany do złożenia apelacji od wyroku pierwszej instancji stwierdzającego nieważność małżeństwa. Posiadał również uprawnienia do złożenia apelacji do trzeciej instancji, jeśli w sumieniu uważał dwa zgodne wyroki odrębnych instancji za niesprawiedliwe ${ }^{7}$. Ustanowienie przez papieża urzędu obrońcy węzła miało w zamierzeniu stać na straży integralności procesu i bronić ważności, świętości oraz nierozerwalności małżeństwa chrześcijańskiego w granicach prawa kanonicznego ${ }^{8}$. Obrońca węzła stał się „specyficzną stroną" w kanonicznym procesie, konieczną dla jego integralności, a zarazem i ważności ${ }^{9}$.

Kodeks prawa kanonicznego z 1983 roku nie rozstrzyga jednoznacznie, czy obrońca węzła może być uważany za stronę w procesie. Pomijając kwestie teoretyczne analiz, należy stwierdzić, że obrońca węzła, zarówno rzeczowo,

3 Por. M. Greszata, Iudicium cum principiis..., s. 230.

4 Por. Benedictus XIv, Dei miseratione, w: Codicis Iuris Canonici Fontes, ed. P. Gasparri, vol. 1, Romae 1947, nr 318, s. 695; G. Leszczyński, Rola obrońcy węzła małżeńskiego $w$ procesie o stwierdzenie nieważności małżeństwa, „Prawo Kanoniczne” 49 (2006) nr 3-4, s. 51.

5 Por. A. Wójcik, Rola aktywności obrońcy węzła małżeńskiego $w$ procesie o stwierdzenie nieważności małżeństwa, w: Urzędy sądowe - władza i służba, red. T. Rozkrut, Tarnów 2005, s. 90 .

6 Por. R. Biernat, Obrońca węzła małżeńskiego w procesach I Instancji Sądu Diecezjalnego $w$ Tarnowie, w: Struktura i działalność Sądu Diecezjalnego $w$ Tarnowie w latach 1983-2015, red. R. Kantor, Kraków 2016, s. 57-58.

7 Por. M. Greszata, Iudicium cum principiis..., s. 230.

8 Por. T. Pawluk, Prawo kanoniczne według Kodeksu Jana Pawła II, t. 4: Doczesne dobra Kościoła. Sankcje w Kościele. Procesy, Olsztyn 1990, s. 200; G. Leszczyński, Rola obrońcy..., s. 51-52.

9 Por. M. Greszata, Iudicium cum principiis..., s. 230. 
jak i procesowo został ze stronami procesowymi zrównany w prawach ${ }^{10}$. Ma on wszelkie uprawnienia przysługujące stronom procesu. Reprezentuje wspólnotę wiernych Kościoła broniąc nierozerwalności i sakramentalności małżeństwa. Kwestia ta staje się klarowna, gdy weźmie się pod uwagę podział na strony procesowe i strony sporu. W świetle powyższego podziału obrońca węzła jest przykładem strony procesu. Natomiast w sprawie stwierdzenia nieważności małżeństwa występuje wobec sędziego jako przedstawiciel Kościoła katolickiego ${ }^{11}$. Nie reprezentuje on ani siebie, ani biskupa diecezjalnego, ale Kościół jako inicjatora postępowania sądowego. Prawo kanoniczne zobowiązuje sędziego w trybunale kościelnym do traktowania obrońcy węzła na równi ze stronami procesowymi, ale pod warunkiem, że ustawa nie stanowi inaczej ${ }^{12}$.

Nie podlega dyskusji, że sam urząd obrońcy węzła jest ustanawiany w Kościele katolickim w celu ochrony szczególnego aspektu dobra publicznego w dwóch kategoriach. Pierwsza z nich to sprawy, które dotyczą nieważności przyjętych przez katolika święcen ${ }^{13}$. Drugą kategorię stanowią natomiast sprawy o stwierdzenie nieważności małżeństwa ${ }^{14}$ i rozwiązanie węzła małżeńskiego ${ }^{15}$. Obecne prawodawstwo Kościoła nakazuje, by dla wszystkich spraw sądowych o nieważność małżeństwa, w każdym sądzie diecezjalnym i międzydiecezjalnym ustanowić na stałe przynajmniej jednego obrońcę węzła małżeńskiego - jego powołanie jest obligatoryjne ${ }^{16}$. Nakaz ten wynika $\mathrm{z}$ faktu, że praktycznie wszystkie sądy biskupie zajmują się sprawami o stwierdzenie nieważności węzła małżeńskiego. Co więcej - w przeważającym procencie sprawy te przeważają nad innymi sprawami prowadzonymi

${ }^{10}$ Szerzej na ten temat: M. Greszata, Iudicium cum principiis..., s. 231-232.

${ }^{11}$ Por. M. Greszata, Iudicium cum principiis..., s. 232.

${ }_{12}$ Por. Codex iuris canonici auctoritate Ioannis Pauli PP. II promulgatus, 25.01.1983 [dalej: CIC], „Acta Apostolicae Sedis” 75 (1983) pars 2, can. 1434; J. Krukowski, Artykuł 3. Promotor sprawiedliwości, obrońca węzła i notariusz, w: Komentarz do Kodeksu Prawa Kanonicznego. Tom v. Księga viı: Procesy, red. J. Krukowski, Poznań 2007, s. 50.

${ }^{13}$ CIC, can. 1708-1712.

${ }^{14}$ CIC, can. 1671-1691.

${ }^{15}$ CIC, can. 1697-1706; por. J. Krukowski, Artykuł 3. Promotor sprawiedliwości, obrońca węzła $i$ notariusz, s. 48.

${ }^{16}$ Por. Pontificium Consilium de Legum Textibus, Instructio Dignitas connubii servanda a tribunalibus dioecanis et interdioecesanis in pertractandis causis nullitatis matrimonii [dalej: DC], 25.01.2005, Città del Vaticano 2005, art. 53, \$1; R. Biernat, Obrońca węzła małżeńskiego..., S. 56 . 
w sądach kościelnych ${ }^{17}$. Prawo do mianowania obrońcy węzła małżeńskiego ma biskup diecezjalny, ale przysługuje ono także administratorowi diecezji, z zachowaniem przepisów prawa kanonicznego. Nie wystarczy samo mianowanie obrońcy węzła małżeńskiego przez biskupa diecezjalnego, ale jest konieczne, by faktycznie był on obecny, a przynajmniej wezwany do stawienia się w sprawach, w których jego uczestnictwo jest wymagane przez prawo kanoniczne $^{18}$. Prawo kościelne zezwala wikariuszowi sądowemu wyznaczyć dekretem także pomocników obrońcy węzła małżeńskiego, jeśli uzna to za konieczne.

W literaturze kanonistycznej spotyka się różne stanowiska odnośnie do obrońcy węzła ${ }^{19}$. Część kanonistów uważa, że obrońcę węzła należy traktować jako stronę pozwaną w procesie o stwierdzenie nieważności małżeństwa. Zwolennicy tej tezy odwołują się do faktu, że w niektórych procesach małżonkowie nie zwracają się do sądu jako strony przeciwstawne, z których strona powodowa jest zainteresowana uzyskaniem orzeczenia nieważności, natomiast strona pozwana opowiada się za jego ważnością, ale przeciwnie - obie strony zgodnie proszą sąd o stwierdzenie nieważności swego związku małżeńskiego. Trafniejsza wydaje się jednak teza, według której stroną pozwaną jest władza kościelna, która zawsze jest zainteresowana uzyskaniem przez sąd potwierdzenia ważności zaskarżonego małżeństwa, przy poszanowaniu prawdy obiektywnej. Patrząc z tej pespektywy, uznaje się, że obrońca węzła małżeńskiego występuje w procesie jako reprezentant Kościoła katolickiego ${ }^{20}$. Wedle innych opinii obrońca węzła nie jest stroną $\mathrm{w}$ procesie, lecz trzecią osobą interweniującą w procesie, zwłaszcza jeśli opinie dwóch stron procesowych, co do ważności czy nieważności małżeństwa, są ze sobą sprzeczne. Można spotkać się z stanowiskiem, że jest stroną sui generis bądź reprezentantem strony ${ }^{21}$.

Obrońca węzła jest wyznaczany w chwili powołania składu sędziowskiego, natomiast formalnie rozpoczyna działanie od momentu powiadomienia go o przyjęciu skargi powodowej. Jego zadaniem jest przedstawienie tego

17 Por. CIC, can. 1432; DC, art. 53.

${ }_{18}$ Por. J. Krukowski, Artykuł 3. Promotor sprawiedliwości, obrońca węzła i notariusz, s. 50.

19 Por. J. Krukowski, Artykuł 3. Promotor sprawiedliwości, obrońca węzła i notariusz, s. 49.

${ }^{20}$ J. Krukowski, Artykuł 3. Promotor sprawiedliwości, obrońca węzła i notariusz, s. 49; por. Z. Grocholewski, Parte convenuta nelle cause di nullità di matrimonio, w: Vitam impendere Magisterio, a cura di D. J. Andrés Gutiérrez, Roma 1993, s. 41-55.

${ }^{21}$ Por. G. Leszczyński, Rola obrońcy..., s. 52. 
wszystkiego, co w sposób logiczny może świadczyć za ważnością i trwałością węzła małżeńskiego ${ }^{22}$. Prawodawca kościelny stwierdza, że obrońca węzła małżeńskiego ma prawo głosu zawsze, gdy takie prawo posiadają strony procesu $^{23}$. Sędzia jest zobowiązany powiadomić obrońcę węzła o sprawie przyjętej do prowadzenia, a także udzielić mu głosu, wzywać na sesję, przekazywać akta sprawy do wglądu zawsze, gdy podejmowana jest decyzja $\mathrm{z}$ udziałem stron procesu ${ }^{24}$. A zatem sędzia jest zobowiązany do wezwania obrońcy węzła małżeńskiego za każdym razem, gdy udziela prawa głosu stronom. Cieszy się on niezależnością sądu. Podlega z mocy prawa wikariuszowi sądowemu, a w konkretnym procesie przewodniczącemu trybunału ${ }^{25}$. Może on być powołany na samym początku procesu o stwierdzenie nieważności małżeństwa lub podczas jego trwania ${ }^{26}$.

\section{Wymagania prawne stawiane osobie mającej pełnić urząd obrońcy węzła małżeńskiego}

Przepisy Kodeksu prawa kanonicznego z 1983 roku określają wymogi, jakie powinna spełniać osoba mająca pełnić urząd obrońcy węzła małżeńskiego w procesach o stwierdzenie nieważności małżeństwa. Kodeks z 1983 roku znacznie rozszerzył kryteria dotyczące wyboru osoby na urząd obrońcy węzła względem przepisów zawartych w Kodeksie prawa kanonicznego z 1917 roku, w których wymagano, by obrońca węzła był osobą posiadająca święcenia. W obecnym prawie kanonicznym nie ma już takiego nakazu. A zatem nowością jest to, że urząd ten może pełnić osoba świecka ${ }^{27}$. Urząd obrońcy węzła może sprawować osoba duchowna (diakon, prezbiter i biskup), jak i osoba świecka: kobieta i mężczyzna. Sam św. Jan Paweł II w przemówieniu do członków Trybunału Roty Rzymskiej przypomniał, że rola i zadania obrońcy węzła małżeńskiego jest bardzo ważna w sądownictwie kościelnym

${ }^{22}$ CIC, can. 1432.

${ }_{23}$ Por. M. Greszata, Iudicium cum principiis..., s. 231.

${ }^{24}$ Por. CIC, can. 1434, can. 1678, \$1; DC, art. 59, art. 159, § 1; M. Greszata, Iudicium cum principiis..., s. 231.

${ }^{25}$ CIC, can. 1432.

${ }^{26}$ DC, art. 55; por. M. Greszata, Iudicium cum principiis..., s. 230.

${ }_{27}$ Por. R. Biernat, Obrońca węzła matżeńskiego..., s. 56. 
i niezastąpiona ${ }^{28}$. Dlatego nie powinno dziwić, że prawodawstwo kościelne stawia duże wymagania osobie, która ma pełnić urząd obrońcy węzła.

Zmianom uległ także wymóg kwalifikacji akademickich, ponieważ kodeks z 1917 roku wymagał stopnia naukowego doktora prawa kanonicznego lub biegłości w prawie kanonicznym ${ }^{29}$. Natomiast kodeks z 1983 roku nadal utrzymuje w mocy wymóg doktoratu z prawa kanonicznego, ale jednocześnie dopuszcza osoby $\mathrm{z}$ wykształceniem licencjackim $\mathrm{z}$ dziedziny prawa kanonicznego, nie bierze natomiast pod uwagę biegłości w prawie ${ }^{30}$. Są to wymogi intelektualne, które stawia przyszłym obrońcom węzła Kościół katolicki.

Prawodawca wymaga również od kandydata na urząd obrońcy węzła małżeńskiego, by cieszył się dobrym imieniem, nieposzlakowaną opinią, nienaganną zarówno w przeszłości, jak i aktualnie, a także odznaczał mądrością oraz gorliwością w dążeniu do sprawiedliwości i prawdy. Powinien być szczególnie wyczulony na sytuacje naruszania prawa kanonicznego ${ }^{31}$. Biskup diecezjalny, jeśli ma wątpliwości co do osoby, która ma pełnić ten urząd, nie powinien jej mianować, dopóki nie upewni się, że spełnia wszystkie wymagania prawne co do pełnienia tego zaszczytnego urzędu w sądownictwie kościelnym. Musi również wykazać się znajomością antropologii chrześcijańskiej, ponieważ jego interwencja skierowana jest ku szukaniu prawdy o zaskarżonym małżeństwie ${ }^{32}$. I choć niespełnienie któregokolwiek z powyższych wymogów nie powoduje nieważności uzyskanego urzędu, to jednak czyni nominację niegodziwą.

Osoba pełniąca urząd obrońcy węzła małżeńskiego powinna łączyć wiedzę prawniczą na temat sakramentalnego małżeństwa $\mathrm{z}$ doświadczeniem duszpasterskim, ale także ze znajomością podstaw nauki psychiatrii i psychologii. Obrońca węzła, by dobrze wypełnił swoją posługę, nie może ograniczać się do pobieżnego przeczytania akt sprawy i „biurokratycznych i ogólnikowych

${ }^{28}$ Joannes Paulus PP. II, Allocutio ad Romanae Rotae Auditores simul cum officiali - bus et advocatis coram admissos, anno forensi ineunte, 25.01.1988, „Acta Apostolicae Sedis” [dalej: AAs] 8 o (1988), s. 1178-1185.

${ }_{29}$ Por. M. Stasiak, Dylemat defensora: chronić instytucję małżeństwa czy dobro osoby, w: Divina et humana. Księga Jubileuszowa w 65. rocznicę urodzin Księdza Profesora Henryka Misztala, red. A. Dębiński, W. Bar, P. Stanisz, Lublin 2001, s. 716.

${ }^{30}$ Por. M. Greszata, Iudicium cum principiis..., s. 231.

${ }^{31}$ CIC, can. 1435; por. DC, art. 56, $\$ 4$.

${ }^{32}$ Por. R. Biernat, Obrońca węzła małżeńskiego..., s. 56. 
odpowiedzi”33. Ryszard Biernat, kanonista mający doświadczenie wieloletniej pracy jako obrońca węzła małżeńskiego w Sądzie Diecezjalnym w Tarnowie twierdzi, że mianowana osoba na urząd obrońcy węzła powinna być wolna od innych duszpasterskich obowiązków, które by odciągały ją od zobowiązań wynikających z pełnionego urzędu. Powinna także poszerzać swoją wiedzę z dziedziny prawa kanonicznego i nauk społecznych oraz uczestniczyć w spotkaniach mających na celu usprawnienie posługi obrońcy węzła, podczas których możliwa jest wymiana doświadczeń oraz wskazanie zaistniałych "potknięć"34.

\section{Prawa i obowiązki obrońcy węzła małżeńskiego}

Obowiązkiem obrońcy węzła małżeńskiego jest przedstawienie tego wszystkiego, co przemawia przeciw orzeczeniu nieważności małżeństwa lub przeciw rozwiązaniu węzła małżeńskiego, lecz zawsze z uwzględnieniem zasady poszanowania prawdy ${ }^{35}$. Należy podkreślić, że między obrońcą węzła a stronami istnieją zasadnicze różnice. Obrońca węzła nie może rozpocząć procesu o stwierdzenie nieważności małżeństwa, ale ma prawo - w przeciwieństwie do strony powodowej i pozwanej - uczestniczyć w przesłuchaniu stron, świadków i biegłych oraz zapoznać się z aktami sądowymi przed ich opublikowaniem ${ }^{36}$. Umożliwia mu to stałą obecność w kanonicznym procesie małżeńskim i mobilizuje do aktywnego zaangażowania w toczące się kanoniczne postępowanie dotyczące zaskarżonego małżeństwa. Taka postawa obrońcy wpływa na „ekonomię procesową". Uprawnienie to należy postrzegać jako normę o dużym znaczeniu procesowym. Podkreśla to aktywną funkcję obrońcy węzła w procesie o stwierdzenie nieważności małżeństwa. W praktyce jest on bardzo pomocny, ponieważ wskazuje również na nieprawidłowości procesowe ${ }^{37}$.

Święty Jan Paweł II wskazuje podstawowe zadania obrońcy węzła. Pierwszym $\mathrm{z}$ nich jest czuwanie nad tym, by proces przebiegał zgodnie z przepisami

${ }^{33}$ Franciszek, W obronie węzła małżeńskiego. Audiencja dla uczestników sesji plenarnej Najwyższego Trybunału Sygnatury Apostolskiej, 8.11.2013, http://www.opoka.org.pl (7.09.2017).

${ }^{34}$ Szerzej na ten temat: R. Biernat, Obrońca węzła małżeńskiego..., s. 73-74.

${ }_{35}$ Por. J. Krukowski, Artykuł 3. Promotor sprawiedliwości, obrońca węzła i notariusz, s. 48.

${ }^{36}$ CIC, can. 1678, \$ 1; por. DC, art. 159, \$1, 1-2; G. Leszczyński, Rola obrońcy..., s. 52-53.

37 Por. H. Stawniak, Tytuł v. Wprowadzenie sprawy, w: Komentarz do Instrukcji procesowej „Dignitas connubii”, red. T. Rozkrut, Sandomierz 2007, s. 136. 
prawa kanonicznego, aby solidnie zgromadzono wszelkie dowody w celu ukazania prawdy o danym małżeństwem, nie pomijając tych, które mogłyby potwierdzić ważność zaskarżonego małżeństwa. Ważne jest także dbanie o to, by w argumentacji używanej w procesie miały swoje odbicie chrześcijańska antropologia, nauczanie i jurysprudencja Kościoła w dziedzinie małżeństwa. Kolejnym zadaniem jest proponowanie i przedstawianie logicznych argumentów, które racjonalnie broniłyby ważności małżeństwa. Następnym - zaskarżanie wyroków, które według obrońcy węzła byłyby nieważne lub wnoszenie apelacji do wyższej instancji od niesprawiedliwego wyroku $^{38}$.

Najważniejsze zadanie, jakie stoi przed obrońcą węzła małżeńskiego, stanowi ochrona dobra publicznego, jakim jest małżeństwo. Małżeństwo jest ważne, jeśli zostało zawarte zgodnie z prawem kanonicznym. Uprawnieniem obrońcy węzła jest ostatnie słowo w fazie dyskusji sprawy ${ }^{39}$. Nie powinien on zadowalać się jedynie ogólną znajomością akt sprawy, ale poprzez dogłębną analizę akt wypowiedzieć się jednoznacznie co do argumentów przemawiających za ważnością małżeństwa ${ }^{40}$. Obrońca węzła miałby lepszą ocenę całej sprawy, gdyby uczestniczył w przesłuchaniach i na bieżąco redagował wnioski. Inaczej odbiera się tekst zeznań napisany w protokole, a inaczej, jeśli widzi się osobę składającą zeznanie. Powinien starać się o to, aby wyjaśniać, odkrywać to wszystko, co sprzyja zawartemu małżeństwu. Wnioski obrońcy węzła powinny być sporządzone w formie pisemnej, chyba że przyjmie się zasadę ustnego przekazania wniosków sędziemu w obecności notariusza sądowego, który je zapisze ${ }^{41}$.

Dotarcie do prawdy obiektywnej nie oznacza, że obrońca węzła winien bronić małżeństwa wbrew logice i wiarygodnym dowodom ${ }^{42}$ - byłoby to przeciwne dochodzeniu do poznania prawdy obiektywnej, która jest celem kanonicznego procesu sądowego. Takie wymaganie - skierowane do obrońcy węzła - sugerowałoby niepotrzebny wysiłek, niczemu niesłużący

${ }^{38}$ Por. R. Biernat, Obrońca węzła małżeńskiego..., s. 61.

39 CIC, can. 1603, §3; por. G. Leszczyński, Rola obrońcy..., s. 53.

${ }^{40}$ Por. G. Leszczyński, Rola obrońcy..., s. 52.

${ }^{41}$ Por. R. Biernat, Obrońca węzła małżeńskiego..., s. 63.

${ }^{42}$ Por. Pius XII, Allocutio ad praelatos auditores ceterosque officiales et administros tribunalis, Sacrae Romanae Rotae necnon eiusdem tribunalis advocatos et procuratores, 2.10.1944, AAS 36 (1944), s. 283. 
i pozbawiony wartości ${ }^{43}$. Obrońca węzła powinien postępować racjonalnie, dlatego nie musi w każdej sprawie wnosić apelacji od wyroku orzekającego nieważność małżeństwa ani tworzyć „sztucznych przeszkód” i „za wszelką cenę" w każdej sprawie walczyć w obronie ważności małżeństwa, odrzucając racjonalność swoich działań ${ }^{44}$. Święty Jan Paweł II w przemówieniu do pracowników Trybunału Roty Rzymskiej stwierdził, że obowiązkiem obrońcy węzła małżeńskiego nie jest zdefiniowanie za wszelką cenę rzeczywistości nieistniejącej, przeciwstawienie się prośbie strony powodowej, opartej na faktach, ale sugerowanie swoich uwag ${ }^{45}$. Warto zauważyć stwierdzenie kanonisty Grzegorza Leszczyńskiego, który stoi na stanowisku, że nie jest porażką obrońcy orzeczenie sądu, że małżeństwo nie zaistniało, lecz będzie porażką wtedy, gdy przyczyni się on do wydania wyroku, który jest niezgodny z prawdą obiektywną. Jeśli wyrok o stwierdzenie nieważności małżeństwa jest zgodny z prawdą obiektywną, a obrońca węzła uczyni wszystko, aby dopomóc sędziemu w uzyskaniu moralnej pewności koniecznej do wydania sprawiedliwego wyroku, spełnił on swoje zadanie wynikające z pełnionego urzędu publicznego w sądownictwie kościelnym ${ }^{46}$.

Należy podkreślić konieczność obecności obrońcy węzła małżeńskiego w kanonicznym procesie o stwierdzenie nieważności małżeństwa ${ }^{47}$. Zakres jego działań określa prawo kanoniczne. Jest on urzędowym przedstawicielem Kościoła katolickiego, wyznaczonym do udziału w sprawach dotyczących węzła małżeńskiego. Obrońca węzła to urząd przewidziany dla procesowej obrony, a w pewnym sensie także ochrony ważności i nietykalności węzła małżeńskiego ${ }^{48}$. Obrońca węzła uosabia zasadę przychylności prawa wobec małżeństwa, jak i troskę Kościoła o małżeństwo, dlatego ma on prawo i obowiązek wypełniać z powagą i rzetelnością swoją misję w każdym procesie małżeńskim ${ }^{49}$.

Szczególnie ważne jest, by obrońca węzła małżeńskiego uczestniczył w każdym etapie procesu, a nie jedynie zapoznawał się z aktami sprawy.

${ }^{43}$ Por. G. Leszczyński, Rola obrońcy..., s. 53-54.

${ }^{44}$ Por. J. Krukowski, Artykuł 3. Promotor sprawiedliwości, obrońca węzła i notariusz, s. 49.

45 Por. Ioannes Paulus II, Ad Sacrae Romanae Rotae Tribunalis Praelatos Auditores, Officiales et Advocatos coram admissos, 28.12.1982, AAs 74 (1982), s. 453.

${ }^{46}$ Por. G. Leszczyński, Rola obrońcy..., s. 54.

47 DC, art. 56, \$1; por. M. Greszata, Iudicium cum principiis..., s. 231.

${ }^{48}$ Por. M. Greszata, Iudicium cum principiis..., s. 230-231.

49 Por. G. Leszczyński, Rola obrońcy..., s. 52. 
Dlatego zadania obrońcy w procesie o stwierdzenie nieważności małżeństwa można podzielić na etapy: wstęp, instrukcja, dyskusja i wyrokowanie. $\mathrm{Na}$ każdym $\mathrm{z}$ tych etapów toczącego się procesu jego udział jest niezbędny ${ }^{50}$. Pojawia się on $\mathrm{w}$ procesie sądowym $\mathrm{w}$ chwili ukonstytuowaniu trybunału do konkretnej sprawy procesowej przez wikariusza sądowego, natomiast formalnie może działać od momentu powiadomienia go o przyjęciu skargi powodowej, co jest jednoznaczne $\mathrm{z}$ decyzją o przeprowadzeniu procesu i z formalnym ukonstytuowaniem się stron. Po ustaleniu formuły sporu obrońca ma prawo do proponowania środków dowodowych. Szczególną rolę obrońca węzła małżeńskiego odgrywa w czasie dyskusji nad sprawą, co przybiera postać przygotowanych pisemnie uwag przedwyrokowych, pod sankcją nieważności czynności sądowych ${ }^{51}$. Instrukcja procesowa Dignitas connubii stwierdza, że jest rzeczą użyteczną, aby przewodniczący trybunału, zanim podejmie decyzję o przyjęciu lub odrzuceniu wniesionej skargi powodowej, zasięgnął opinii obrońcy węzła małżeńskiego ${ }^{52}$. Kodeks z 1983 roku nie wspomina o takiej możliwości. Jest to nowe uprawnienie wskazujące, że ważna może być konsultacja z obrońcą węzła małżeńskiego ${ }^{53}$. W skazuje to, że w niektórych przypadkach jego udział w procesie rozpoczyna się jeszcze przed formalnym przyjęciem przez sędziego skargi powodowej ${ }^{54}$.

Kwestią dyskusyjną jest sprawa, czy obrońca węzła małżeńskiego ma prawo proponować zmianę ustalonej formuły sporu. Kodeks z 1983 roku stwierdza jednoznacznie, iż raz ustalony przedmiot sporu nie może być ważnie zmieniony inaczej, jak tylko nowym dekretem sędziego, z powodu istotnej przyczyny, na żądanie stron oraz po wysłuchaniu i rozważeniu ich racji5 Zatem zmiana formuły sporu dokonuje się wyłącznie na wniosek strony. Oznacza to, że obrońca węzła małżeńskiego nie może proponować zmiany formuły sporu poprzez propozycję wprowadzenia jakiegoś nowego tytułu nieważności. Leszczyński twierdzi: „trudno zatem zrozumieć, na jakich przesłankach miałby opierać się obrońca w swoim przekonaniu o bezzasadności faktycznej jakiegoś tytułu nieważności określonego w formule sporu,

\footnotetext{
$50 \mathrm{DC}$, art. 56, $\$ 1$.

51 CIC, can. 1433; por. DC, art. 50; M. Greszata, Iudicium cum principiis..., s. 232.

52 Por. DC, art. 119, \$2; H. Stawniak, Tytut v. Wprowadzenie sprawy, s. 186.

53 Por. H. Stawniak, Tytuł v. Wprowadzenie sprawy, w: Komentarz..., s. 186.

54 Por. R. Biernat, Obrońca węzła małżeńskiego..., s. 63-64.

55 CIC, can. 1514; por. G. Leszczyński, Rola obrońcy..., s. 55-56.
} 
niemniej rzeczywiście obrońca ma możliwość wniesienia takiej prośby do sędziego, który następnie samodzielnie podejmuje decyzję"56.

Prawem obrońcy węzła małżeńskiego jest obecność w czasie składania oświadczeń i zeznań przez strony - powodową i pozwaną oraz świadków i biegłych ${ }^{57}$. Prawodawca kościelny upoważnia obrońcę węzła małżeńskiego do przedstawienia sędziemu zagadnień, co do których strona ma być przesłuchana $^{58}$, jak i pytań, które mają być przez sędziego zadane świadkowi w czasie składania przez niego zeznań ${ }^{59}$. Formułowanie przez obrońcę węzła pytań do przesłuchania stron i świadków nie jest obowiązkiem, lecz prawem. Obrońca węzła powinien zatroszczyć się o to, by pytania zadawane w czasie przesłuchania stronom, świadkom były dla nich zrozumiałe. Powinien również proponować sędziemu dowody świadczące przeciwko nieważności małżeństwa lub osłabiające wartość zgromadzonych środków dowodowych zaproponowanych przez stronę powodową. Zasada ta dotyczy także różnego rodzaju dokumentów publicznych i prywatnych przyjętych przez sąd ${ }^{60}$, a także opinii powołanego biegłego. Obrońca węzła małżeńskiego ma obowiązek wskazać na poszczególne zagadnienia. Mogą być one w formie pytań, na które ma odpowiedzieć w swojej opinii biegły, który został powołany do procesu. Dotyczy to zwłaszcza sytuacji spraw sądowych prowadzonych z tytułu niezdolności psychicznej do zawarcia małżeństwa. Jego zadaniem jest też czuwanie, by opinia przygotowana przez biegłego nawiązywała do antropologii chrześcijańskiej i by ekspertyzy biegłych sądowych nie wykroczyły poza ich kompetencje. Powinien być aktywnym podmiotem dialogu pomiędzy biegłymi sądowymi a sędziami. Jednocześnie ma obowiązek śledzenia sposobu wykorzystywania danych z dziedziny psychiatrii i psychologii przy formułowaniu wniosków kanonicznych ${ }^{61}$. W razie błędów czy nadużyć interpretacyjnych obowiązkiem obrońcy węzła jest wskazanie ich sędziemu, aby i w ten sposób zabezpieczyć swoim działaniem dobro małżonków ${ }^{62}$.

\footnotetext{
${ }^{56}$ G. Leszczyński, Rola obrońcy..., s. 56.

57 CIC, can. 1678, \$1; por. R. Biernat, Obrońca węzła małżeńskiego..., s. 61.

${ }^{8}$ CIC, can. 1533; por. G. Leszczyński, Rola obrońcy..., s. 56.

59 CIC, can. 1561; por. G. Leszczyński, Rola obrońcy..., s. 56.

${ }^{60}$ Por. CiC, can. 1539, can. 1545; G. Leszczyński, Rola obrońcy..., s. 57.

${ }^{61}$ Por. R. Biernat, Obrońca węzła małżeńskiego..., s. 59.

${ }^{62}$ Por. G. Leszczyński, Rola obrońcy..., s. 57.
} 
Obrońca węzła małżeńskiego jest zobowiązany zapoznać się ze zgromadzonymi w czasie procesu aktami sądowymi. Ma prawo wglądu na bieżąco do akt sprawy ${ }^{63}$. Wezwanie go przed zamknięciem postępowania dowodowego jest konieczne, ponieważ może on domagać się nowego postępowania dowodowego. Jednakże dopuszczanie go do głosu dopiero w trakcie samej dyskusji sprawy, po zamknięciu postępowania dowodowego, może narazić trybunał na konieczność wznowienia instrukcji. Wszystko to zmierza do tego, by w uwagach przedwyrokowych zajął on stanowisko odnośnie do ważności małżeństwa. Jest zobowiązany do przedstawienia konkretnych faktów i argumentów, które świadczą jego zdaniem o ważności małżeństwa albo zdać się na sprawiedliwość trybunału, gdy jego przeświadczenie o ważności małżeństwa nie jest pewne ${ }^{64}$. Obrońca powinien wskazać te argumenty i fakty, które pomimo jednoznaczności osądu przemawiają za ważnością małżeństwa.

Na wnikliwsze rozważenie zasługuje sytuacja, gdy sam obrońca węzła dochodzi do wniosku, że małżeństwo zostało zawarte nieważnie. Opinie kanonistów w kwestii zachowania się obrońcy w tej sytuacji są podzielone. Niektórzy uważają, że obrońca węzła powinien powstrzymać się od prawa głosu, co w praktyce oznaczałoby przyznanie, iż nie zauważa argumentów przemawiających za ważnością małżeństwa ${ }^{65}$. Są również opinie, że obrońca węzła małżeńskiego powinien starać się wskazać te argumenty, które przynajmniej podają w wątpliwość wiarygodność stron czy świadków lub wartość dowodową poszczególnych faktów, nawet jeśli jest on przekonany o nieważności małżeństwa. Obrońca nie może wprost stwierdzać nieważności małżeństwa, jak i przedstawiać argumentów przemawiających za nieważnością węzła małżeńskiego nawet wtedy, gdy nie znajduje argumentów potwierdzających jego ważnośćc ${ }^{6}$. Nie podlega dyskusji to, że obrońca węzła nie powinien traktować przedstawienia uwag przedwyrokowych mechanicznie, ograniczając się wyłącznie do wskazania kilku fragmentów z zeznań, gdyż dla sędziego istotne są rozumowanie obrońcy i logika jego argumentacji. Uwagi przedstawione w sposób rzetelny zawsze są pomocne i pozwalają

${ }^{63}$ CIC, can. 1678, \$1, 2; por. G. Leszczyński, Rola obrońcy..., s. 58.

${ }^{64}$ Por. G. Leszczyński, Rola obrońcy..., s. 58.

${ }^{65}$ Por. A. Dzięga, Zadania obrońcy węzła małżeńskiego, w: Kościelne prawo procesowe. Materiaty $i$ studia, t. 1, red. A. Dzięga, Lublin 1999, s. 36.

${ }^{66}$ Por. G. Leszczyński, Rola obrońcy..., s. 54. 
dostrzec słabe punkty argumentacji strony powodowej i pozwanej, świadków, jak i sporządzonej na potrzeby toczącego się procesu opinii biegłego ${ }^{67}$.

Wydanie przez sędziego wyroku nie kończy udziału obrońcy węzła w procesie. Najczęstszą jego reakcją w odniesieniu do wyroku jest złożenie przez niego apelacji. Ma to miejsce wówczas, gdy wyrok orzeka nieważność małżeństwa, a zdaniem obrońcy węzła jest to wyrok niesprawiedliwy, to znaczy niezgodny $z$ argumentacją przedstawioną przez niego $w$ uwagach przedwyrokowych. Złożenie apelacji od wyroku stwierdzającego nieważność małżeństwa przez obrońcę węzła powinno nastąpić w bardzo konkretnych przypadkach, o których mówi prawo kanoniczne. Jednym z nich jest brak wezwania obrońcy węzła do udziału w procesie, o ile oczywiście sam nie stawił się i nie zapoznał się z aktami sprawy przynajmniej przed wydaniem wyroku. Obrońca węzła nie może apelować od wyroku stwierdzającego ważność małżeństwa ani też nie powinien tego czynić wówczas, gdy z jego uwag przedwyrokowych wynika, że nie znalazł on argumentów przemawiających za ważnością małżeństwa. W trakcie lektury wyroku mogą pojawić się po stronie obrońcy węzła wątpliwości, jednakże z praktycznego punktu widzenia jest to raczej wątpliwe, jeśli rzeczywiście wypełniał rzetelnie swój urząd poprzez dogłębne zapoznanie się ze wszystkimi aktami sprawy ${ }^{68}$.

\section{Zakończenie}

Podsumowując refleksję nad prawnymi aspektami urzędu obrońcy węzła małżeńskiego w świetle obowiązującego prawa kanonicznego, należy przede wszystkim stwierdzić, że jest to urząd publiczny w sądownictwie kościelnym. Wynika z tego, że obrońca węzła nie jest przedstawicielem samego siebie ani stron procesowych, ale reprezentantem Kościoła katolickiego. Można więc stwierdzić z całą stanowczością, że ma on za sobą przychylność prawa kanonicznego względem spraw dotyczących ważności małżeństwa. Stąd jego rola nie polega na dowodzeniu czegokolwiek, lecz na rozumnym i słusznym podważaniu argumentacji sugerującej nieważność małżeństwa. W tym celu obrońca węzła małżeńskiego powinien wykorzystać wszelkie możliwe sposoby oraz środki, jakie dla tego urzędu przewiduje prawo kanoniczne. Jego udział w procesie o stwierdzenie nieważności małżeństwa powinien mieć

${ }^{67}$ Por. G. Leszczyński, Rola obrońcy..., s. 59.

${ }^{68}$ Por. G. Leszczyński, Rola obrońcy..., s. 59-6o. 
charakter dynamiczny, mający na celu odkrycie prawdy obiektywnej, a nie tylko przedstawienie ogólnych uwag przedwyrokowych. Głównym zadaniem obrońcy węzła jest przedstawienie tego wszystkiego, co przemawia za ważnością węzła małżeńskiego i z tego powodu powinien on uczestniczyć we wszystkich sprawach dotyczących stwierdzenia nieważności małżeństwa. Posługa obrońcy węzła małżeńskiego wymaga znajomości prawa kanonicznego, ale i umiejętności łączenia wiedzy naukowej oraz doświadczenia z konkretnymi sytuacjami ludzkimi.

\section{Bibliografia}

Benedictus XIV, Dei miseratione, w: Codicis Iuris Canonici Fontes, ed. P. Gasparri, vol. 1, Romae 1947, nr 318, s. 691-710.

Biernat R., Obrońca węzła małżeńskiego w procesach I Instancji Sądu Diecezjalnego $w$ Tarnowie, w: Struktura i działalność Sądu Diecezjalnego w Tarnowie w latach 1983-2015, red. R. Kantor, Kraków 2016, s. 55-74.

Codex iuris canonici auctoritate Ioannis Pauli PP. II promulgatus, 25.01.1983, „Acta Apostolicae Sedis" 75 (1983) pars 2, s. 1-301.

Dzięga A., Zadania obrońcy węzła małżeńskiego, w: Kościelne prawo procesowe. Materiały i studia, t. 1, red. A Dzięga, Lublin 1999, s. 23-40.

Franciszek, $W$ obronie węzła małżeńskiego, 8.11.2013. Audiencja dla uczestników sesji plenarnej Najwyższego Trybunału Sygnatury Apostolskiej, http://www.opoka.org.pl (7.09.2017).

Greszata M., Iudicium cum principiis. Kodeksowa weryfikacja wybranych zasad procesowych w kanonicznych sprawach o nieważność matżeństwa, Lublin 2008. Grocholewski Z., Parte convenuta nelle cause di nullità di matrimonio, w: Vitam impendere Magisterio, a cura di D. J. Andrés Gutiérrez, Roma 1993, s. 41-55.

Joannes Paulus II, Ad Sacrae Romanae Rotae Tribunalis Praelatos Auditores, Officiales et Advocatos coram admissos, 28.12.1982, „Acta Apostolicae Sedis” 74 (1982), S. 453.

Joannes Paulus PP. II, Allocutio ad Romanae Rotae Auditores simul cum officiali bus et advocatis coram admissos, anno forensi ineunte, 25.01.1988, „Acta Apostolicae Sedis" 8o (1988), s. 1178-1185.

Krukowski J., Artykuł 3. Promotor sprawiedliwości, obrońca węzła i notariusz, w: Komentarz do Kodeksu Prawa Kanonicznego. Tom v. Księga vir: Procesy, red. J. Krukowski, Poznań 2007, s. 46-55. 
Leszczyński G., Rola obrońcy węzła małżeńskiego w procesie o stwierdzenie nieważności małżeństwa, „Prawo Kanoniczne” 49 (2006) nr 3-4, s. 51-61.

Pawluk T., Prawo kanoniczne według Kodeksu Jana Pawła II, t. 4: Doczesne dobra Kościoła. Sankcje w Kościele. Procesy, Olsztyn 1990.

Pius XII, Allocutio ad praelatos auditores ceterosque officiales et administros tribunalis, Sacrae Romanae Rotae necnon eiusdem tribunalis advocatos et procuratores, 2.10.1944, „Acta Apostolicae Sedis” 36 (1944), s. 281-284.

Pontificium Consilium de Legum Textibus, Instructio Dignitas connubii servande a tribunalibus dioecanis et interdioecesanis in pertractandis causis nullitatis matrimonii, 25.01.2005, Città del Vaticano 2005.

Stasiak M., Dylemat defensora: chronić instytucję małżeństwa czy dobro osoby, w: Divina et humana. Księga Jubileuszowa w 65. rocznicę urodzin Księdza Profesora Henryka Misztala, red. A. Dębiński, W. Bar, P. Stanisz, Lublin 2001, s. 703-721. Stawniak H., Tytuł v. Wprowadzenie sprawy, w: Komentarz do Instrukcji procesowej „Dignitas connubii”, red. T. Rozkrut, Sandomierz 2007, s. 179-214.

Wenz W., Wróblewski P., Urząd obrońcy węzła i procesowe decyzje sędziego na etapie wyrokowania, Warszawa 2007.

Wójcik A., Rola aktywności obrońcy węzła małżeńskiego w procesie o stwierdzenie nieważności małżeństwa, w: Urzędy sądowe - władza i służba, red. T. Rozkrut, Tarnów 2005, s. 89-99.

\section{Streszczenie}

Rozważając problematykę związaną z urzędem obrońcy węzła małżeństwa, należy stwierdzić, że jest to instytucja konieczna dla dobra wspólnego Kościoła katolickiego. Przesłanką do ustanowienia obrońcy węzła była ochrona dobra publicznego. Nie jest on przedstawicielem samego siebie ani stron procesowych, ale reprezentantem Kościoła. Można więc stwierdzić, że ma on za sobą przychylność prawa kanonicznego względem spraw dotyczących ważności małżeństwa. Stąd jego rola nie polega na dowodzeniu czegokolwiek, lecz na rozumnym i słusznym podważaniu argumentacji sugerującej nieważność małżeństwa. Jego udział w procesie o stwierdzenie nieważności małżeństwa powinien mieć charakter dynamiczny, mający na celu odkrycie prawdy obiektywnej. Głównym zadaniem jest przedstawienie tego wszystkiego, co przemawia za ważnością węzła małżeńskiego. Posługa obrońcy węzła małżeńskiego wymaga znajomości prawa kanonicznego, ale i umiejętności łączenia wiedzy naukowej oraz doświadczenia z konkretnymi sytuacjami ludzkimi. 


\section{Słowa kluczowe}

obrońca węzła, małżeństwo, proces, prawda obiektywna

\section{Summary}

\section{Legal Aspects of the Office of the Defender of the Marriage Bond in the Process of Annulment of Marriage}

Considering the issues related to the office of a defender of the marriage bond it is clear that the existence of this office is necessary for the common good of the Catholic Church. The reason for establishing the office of the defender was the need to protect the public interest. The defender does not represent himself or any party involved in the process but he is a representative of the Church. Therefore, it appears his service is supported by the canon law when it comes to the issues related to validity of a marriage. Hence, the defender is not to prove anything but to reasonably and properly dispute arguments made by the parties that suggest the invalidity of a marriage. The defender in the process to declare nullity of a marriage should participate in it actively so as to be able to uncover the objective truth. The main task of the defender is to present everything that argues in favour of validity of a marriage. The service of a defender of the marriage bond requires a good command of canon law as well as the ability to combine the scientific knowledge and the experience with particular human situations.

\section{Keywords}

a defender of the marriage bond, marriage, process, the objective truth 